\title{
Bridging Chemotherapy: Multiple Myeloma
}

\author{
Salomon Manier, Artur Jurczyszyn, and David H. Vesole
}

\section{Should All MM Patients Receive Bridging Therapy?}

In the phase 2 KarMMa study, $88 \%$ of the patients received bridging therapy with only a 5\% response (Munshi et al. 2021). In the CARTITUDE 1 trial, 75\% of the patients received bridging therapy, with a reduction in tumour burden observed in $34 \%$ of the patients prior to cilta-cel infusion, but no patients achieved a CR or better while on bridging therapy (Madduri et al. 2019). Bridging therapy is recommended for virtually all patients. An exception can be discussed for patients with slowly progressive disease, who may not need to receive bridging therapy after leukapheresis; however, this strategy exposes them to a risk of rapid progression later during the manufacturing period. In the future, with allogeneic CAR-T cells, bridging therapy will likely not be necessary because the time between patient inclusion and CAR-T cell infusion is much reduced.

\footnotetext{
S. Manier $(\square)$

Department of Hematology, Lille University, CHU Lille, Lille, France e-mail: Salomon.MANIER@ chru-lille.fr
}

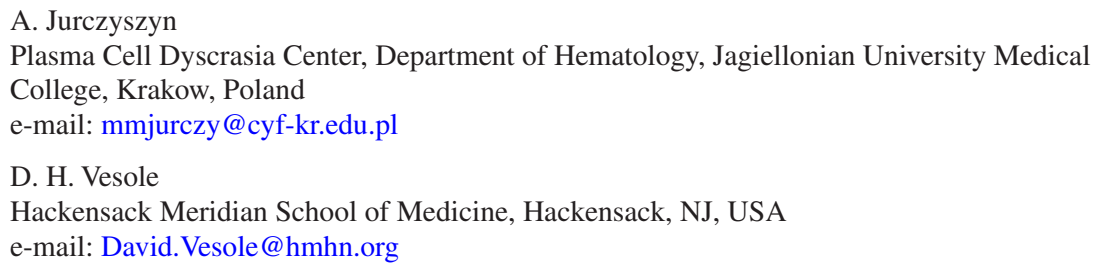




\section{Timeframe to Use Bridging Treatments}

Bridging therapy can be started immediately after leukapheresis. Most clinical trials do not permit the use of any bridging therapy within 2 weeks prior to lymphodepletion to allow for haematologic recovery and to prevent any interaction between the drugs and the CAR-T cells (Munshi et al. 2021; Madduri et al. 2019).

\section{Choice of Treatment}

Several clinical trials allow only agents to which the patients have been previously exposed. However, this strategy can limit the efficacy of bridging therapy if patients are refractory to their previous treatments. Therefore, bridging therapies are typically personalized to each patient according to previous lines of treatment, disease characteristics, and pre-existing toxicities. All treatments can be considered for bridging therapy, including proteasome inhibitors, immunomodulatory drugs, antiCD38 antibodies, targeted therapies, and conventional chemotherapies, with the exception of anti-BCMA targeting therapies in the case of BCMA-targeting CAR-T cells to avoid saturation of antigens. The risk of prolonged cytopenia and the risk of infection should also be taken into account when considering conventional chemotherapies. Involved field radiation therapy has been safely used during bridging (Manjunath et al. 2020).

\section{Key Points}

- Virtually all patients should receive bridging therapy to prevent rapid progression of the disease during the manufacturing period.

- All treatments can be used with the exception of anti-BCMA therapies in the case of BCMA-targeting CAR-T cells.

\section{References}

Madduri D, Usmani SZ, Jagannath S, et al. Results from CARTITUDE-1: a phase 1b/2 study of JNJ-4528, a CAR-T cell therapy directed against B-cell maturation antigen (BCMA), in patients with relapsed and/or refractory multiple myeloma (R/R MM). Blood. 2019;134(Suppl 1):577.

Manjunath SH, Cohen AD, Arscott WT, Maity A, Plastaras JP, Paydar I. Is Bridging Radiation (RT) Safe with B Cell Maturation Antigen-targeting Chimeric Antigenic Receptor T Cells (CART-BCMA) Therapy? ASTRO. 2020;1104

Munshi NC, Anderson LD Jr, Shah N, et al. Idecabtagene vicleucel in relapsed and refractory multiple myeloma. N Engl J Med. 2021;384(8):705-16. 
Open Access This chapter is licensed under the terms of the Creative Commons Attribution 4.0 International License (http://creativecommons.org/licenses/by/4.0/), which permits use, sharing, adaptation, distribution and reproduction in any medium or format, as long as you give appropriate credit to the original author(s) and the source, provide a link to the Creative Commons license and indicate if changes were made.

The images or other third party material in this chapter are included in the chapter's Creative Commons license, unless indicated otherwise in a credit line to the material. If material is not included in the chapter's Creative Commons license and your intended use is not permitted by statutory regulation or exceeds the permitted use, you will need to obtain permission directly from the copyright holder.

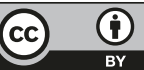

